\title{
Indigenous Onto-Epistemologies and Pedagogies of Care and Affect in Aotearoa
}

\author{
JENNY RITCHIE \\ Department of Education, Te Whare Wānanga o Wairaka - \\ Unitec Institute of Technology, Auckland, New Zealand
}

\begin{abstract}
This article reflects on research conducted in one kindergarten that was part of a wider project focusing on 'caring for ourselves, others and the environment' in early years education in Aotearoa New Zealand. The project drew upon both Māori and western theoretical frames. In this article I respond to Bruno Latour's suggestion that we renew our theoretical considerations to make our practice more responsive to 'matters of concern'. The interlinked matters of concern that are the focus of this article are the endangered status of both Indigenous peoples' worldviews and of the wellbeing of the planet. Early childhood teachers during the project introduced Māori (Indigenous) seasonal and healing practices within their daily pedagogies, in some small ways perhaps transcending the ongoing disruption and intergenerational trauma of the history of colonisation. It is argued that indigenous ways of being, knowing, and doing enact an ethic of biocentric relationality which, when applied through early childhood pedagogies, offer a source of hope in this era of anthropogenic climate crisis.
\end{abstract}

\section{Introduction}

The first section of this article discusses two interrelated 'matters of concern' of relevance to childhood studies and early childhood care and education. Both concerns arise from the impact of the industrial exploitation of our planet through initially colonisation and more recently globalised corporate capitalism. The first concern is the impact on Indigenous peoples who have faced dislocation from their traditional lands, along with the loss of languages and disruption to their traditional belief systems and practices. The second concern is the impact of anthropogenic climate change which is now recognised as threatening the stability of life on the planet (Costello et al, 2009; Intergovernmental Panel on Climate Change, 2013). These concerns are interrelated in that as colonisation and globalisation increasingly exploits geographic locales, the linguistic, cultural, and biodiversity of those areas is impacted (Gorenflo et al, 2012). The next section of the article considers localised natureculture dialogue as exemplified by Indigenous peoples as holding potential to counter these impacts. The article then proceeds to draw upon material from a recent study in a kindergarten in Aotearoa New Zealand to illustrate ways in which teachers are facilitating natureculture dialogues in resonance with te ao Māori (Māori worldview) conceptualisations and practices. These pedagogies of care and affect are proposed as a countering praxis to anthropogenic climate change.

\section{Matters of Concern}

Bruno Latour has provoked a discussion of 'matters of concern' (Latour, 2004b). In critiquing the effectiveness of philosophical critique, he highlights the limitations of positivist theorising based on 'matters of fact'. Latour argues that 'matters of fact' are 'only very partial and ... very polemical, 
very political renderings of matters of concern' (p. 232). 'Matters of fact' suffer from being decontextualised from their locatedness within 'gatherings' or assemblages. They can also be captured in service of the capitalist machine, which has cleverly devised the capacity for 'recycling everything aimed at its destruction' (p. 231). Latour asks: 'Can we devise another powerful descriptive tool that deals this time with matters of concern and whose import then will no longer be to debunk but to protect and to care, as Donna Haraway would put it?' (p. 232). This article draws upon two interrelated matters of concern and interwoven conceptual tools which might serve to protect and care. The matters of concern are, firstly, the invisibilisation of indigenous ontoepistemologies by the colonialist project, and, secondly, anthropogenic climate change. Both matters of concern derive from western disregard for the 'Others' of both Indigenous peoples and the environment. The first conceptual tool in response to these matters of concern is the notion of 'caring for ourselves, others and the environment'. The second conceptual tool is revisibilisation and revalidation of indigenous onto-epistemologies, which position humans as part of and reliant upon, rather than superior to and detached from, our local and global world(s). These matters of concern and conceptual tools were the focus of a recent research project in early childhood care and education in Aotearoa New Zealand. The project took up as its central 'matter of concern' apprehension regarding the well-being of the planet, and in response posited the notion of educator 'response-ability' [1] (Haraway, 2012) to promote an ethic of care, and re-visibilisation and revalidation of te ao Māori (Māori worldviews) in the face of this concern. An ethic of care is in this article theorised as an affective force, underpinning the necessary 'response-ability' which is an adapt-ability [2] in service of sustaining the life and well-being of a natureculture, or common world assemblage (Latour, 2004a; Whitehouse, 2011; Haraway, 2012).

Deborah Bird Rose, whose extensive anthropological work has been conducted alongside Indigenous peoples in Australia, has critiqued the adequacy of modernist, humanist responses to the crisis of the Anthropocene, suggesting an alternative 'Earth-wise' conceptualisation of ways of knowing and being that are relational, ethical, inclusive, open and responsive to the vulnerability of the living Earth' (2008, pp. 166-167). Rose proposes that we (re)enter an ethical, dialogic, intersubjective relationship with the more-than-human, entailing an attentiveness and a reflexive mutuality. Ironically, it is due to this depth of relationality with their country and land that Indigenous peoples have suffered gravely as they have seen their lands desecrated by colonisers. Whilst their cosmologies demonstrate reverence for their planet, lands, and all that live alongside them, Indigenous people have suffered the losses of not only their own family members, but of their more-than-human kin, of their lands, mountains, rivers and the creatures that lived upon them (Rose, 2009), historically through the policies and practices of colonisation, and now, increasingly, through the impact of anthropogenic climate change (Rose et al, 2011). This raises the challenge to early childhood educators, as to how we respond to these matters of concern. It is suggested in this article that consideration be given to ways in which we offer opportunities for young children for engagement with the more-than-human world, fostering dispositions of (inter)connectedness within common worlds (Taylor, 2013).

(Re)-formulating responses to the current era of the Anthropocene, whereby anthropogenic climate change is now threatening the stability of our entire planet's well-being, is clearly a matter of urgent concern for those in positions of response-ability, such as educators (Lorimer, 2012; Intergovernmental Panel on Climate Change, 2013). This article considers ways in which pedagogies of care and affect can serve as counter-narrative to modernist dissociatedness from 'nature'. Indigenous philosophies of living closely with the Earth have been dismissed by the colonialist and capitalist expansionist project to exploit resources for individual and corporatist profit. Colonialist, hierarchical binaries have imposed semantic and enacted 'othering' on both 'the natives' and 'the environment' (Rose, 2004; Haraway, 2008; Whitehouse, 2011). Whilst the colonialist project has treated the environment as an inanimate resource which serves only to be exploited by humans for profit, so too have Māori (and other Indigenous) onto-epistemologies been disparaged and disregarded by the dominant culture. Indigenous ways of knowing, being and doing reflect an intrinsic understanding of relationality and connectedness within the world (Martin, 2007, 2008) operating in reciprocal response-ability within 'naturescultures' (Whitehouse, 2011, p. 63). Enforced separation of Indigenous peoples from their lands, forests and rivers has deprived all (both people and more-than-human co-habitants) of the well-being that had previously been sustained. In this article, examples are provided that show how teachers at one kindergarten 
in Hawera, in the North Island of Aotearoa New Zealand, carefully shaped their pedagogical programme and practices to revisibilise and revalidate traditional Māori life-sustaining beliefs and practices, bridging some of the separations between 'nature' and 'culture' imposed by colonialising discourses. Reconceptualising ways of knowing which have separated 'nature' and 'culture' implies recognition of the difficulty of authentically 'knowing' the 'Other' (Levinas, 1987). Western discourse positions people as knowing and 'nature' as 'un-knowing'. This article suggests the alternative of naturecultures-sourced enactment as a pedagogy of care that reflects sensorial embodied knowing with(in) the more-than-human world. Naturecultures-sourced enactment occurs when humans and the more-than-human operate in reciprocal attunement, rather than humans assuming the role of actor on a 'passive' world.

David Abram has suggested that human abstract language and thinking has contributed to our distancing and detachment from the more-than-human world (1996). Language is complicit in shaping and reinforcing the exploitative colonialist discourses which continue to desecrate our planet (Bowers, 2001). The language of globalised western culture masks the ongoing intergenerational pain of colonisation, paralysing many people into a passive amnesia and suspension of ethics (Rose, 2004). This paralysis seriously inhibits postcolonial and posthumanist movement (Bell, 2009) and perpetuates denial of the serious implications of exploiting human, as well as environmental, 'Others'. Post- or counter-colonial praxis revisibilises and revalidates Indigenous peoples, recognising the integrality of their ways of being, knowing and doing within naturecultures, explicitly challenging implied western dualisms such as 'the natural environment', 'pristine wilderness', and 'noble savage'. This revisibilisation and revalidation requires a deliberate unlearning of colonised and colonising assumptions and practices via a conscious attempt to disentangle the mangled discourses of global politics and economics and their impact on local histories and trajectories (McGloin, 2009, p. 40, as cited in Whitehouse, 2011, p. 63). The deliberate pursuit of a state of 'un-knowing' of the inscribed representationalist discourse is an enactment of 'response-ability' (Levinas, 1987; Haraway, 2012). To challenge our immersion within the representationalist, modernist paradigm requires the active pursuit of 'perpetual dis-orientation', a pro-active unthreading and disentanglement from the western canon through entering into relation with Mystery (Levinas, 1987), the intangible, spiritual realm of more-than-human (un)knowing. This process entails letting go of a compulsion to know the 'Other' via positivist means of accessing, assessing, compartmentalising, defining and controlling. It further recognises aspects such as a spiritual dimension that cannot be 'known' through these means.

Rejecting the compartmentalisation and dualism inherent in both modernism and humanism, and replacing this with acknowledgement of our (more-than-human/human) immersion within naturecultures, is a proactive step towards dissociating from these representationalist paradigms. What is further required is a regenerated awareness of the interdependent embodied sensorial relationality between people, creatures, places, and things. This sits at the heart of pedagogies that offer counter-colonial re-envisaging, positing our response-ability for 'thinking-with', that is, coming to our 'knowing' via sensorial awareness derived from our situatedness within these interrelationships (Puig de la Bellacasa, 2012). This is proposed as a serious ethical engagement and necessity in face of the increasingly severe climate crisis of the Anthropocene, this era of human induced impacts which are severely destabilising previous global climactic processes (Rose, 2009: Alberts, 2011).

Indigenous ways of being, knowing and doing can be recognised as modes that enact naturecultures of respectful interdependence. This article provides some examples of work in an early childhood centre that fostered an embodied sensorial response-ability. This pedagogical work was positioned by the teachers in relation to te ao Māori (Māori worldview) conceptualisations which locate humans as intrinsically bound up within naturecultures. In this article, pedagogical response-ability in relation to the 'matter of concern' of anthropogenic climate change is explicated by resituating Indigenous worldviews within early childhood care and education enactment.

\section{Revisibilising Indigenous Ways of Being, Knowing and Doing in Early Childhood}

It is clearly a 'matter of concern' that formerly strong, healthy Indigenous naturecultures have been largely rendered invisible through the impact of globalised colonialism and capitalism (Smith, 
1999/2012). Indigenous wisdoms can provide us with pathways of response-ability in the face of the looming 'matter of concern' of the current anthropogenic climate crisis (Rose, 2002, 2005). Indigenous onto-epistemologies recognise the interdependence and interconnectedness of all within the universe. These worldviews are conceptualised through the acknowledgement of spiritual interrelatedness and reciprocity as underpinning and transcending naturecultures. According to Indigenous (Tewa) scholar, Gregory Cajete, the Lakota phrase 'Mitakuye Oyasin' (we are all related) 'reflects the understanding that our lives are truly and profoundly connected to other people and the physical world' (2005, p. 70). Cajete considers that 'naturecentered' Indigenous peoples worldwide share commonalities of understandings which include a view of interconnectedness and reciprocity between more-than-humans and humans, and that knowledge and learning is sourced through participating in and honouring relationships between humans and the more-than-human world. These deep relationships enable indigenous visionaries 'to directly access knowledge and understanding from primary sources deep within themselves and in the natural world' (p. 74). Indigenous peoples have long demonstrated that ways of knowing, being and doing are sensorially derived from entanglement within local naturecultures.

In this section I consider some of the ways an onto-epistemology of ethical care and affect as naturecultures was enacted within an early childhood care and education setting. The data was contributed by the teachers and children of Hawera Kindergarten, which is located in a small rural community in the central North Island of New Zealand. This was one of ten early childhood care and education services from across Aotearoa whose teachers and families participated in our study, 'Titiro Whakamuri, Hoki Whakamua: we are the future, the present and the past: caring for self, others and the environment in early years' teaching and learning', funded by the New Zealand Teaching and Learning Research Initiative and more fully reported elsewhere (Ritchie et al, 2010).

The teachers at Hawera Kindergarten introduced their 12 month project by focussing on ' $N g \bar{a}$ Marama Māori o te Tau' (The Maori Months of the Year) using the maramataka Māori (Māori planting and fishing calendar). This traditional Māori calendar identifies lunar and seasonally determined optimal timings for traditional tasks. These knowledges have been ascertained over centuries of embedded and responsive lived practice within specific naturecultures. For Māori, the Indigenous peoples of Aotearoa, their whakapapa (geneology) [3] positions both people and morethan-humans, such as birds, trees, mountains and rivers, as fellow descendants of Papatūānuku, the Earth Mother, and Ranginui, the Sky Father, and as cohabitants within shared naturecultures (Penetito, 2009). Carl Te Hira Mika (2012) explains that Māori do not see themselves as separate from the environment:
Māori believe that the self is part of the environment, and hence the self's uptake of anything- emotion, feeling, cognition, even physical attribute - is dependent on the interplay of whakapapa with the natural world. The deep links that Māori have with the natural world - seen and unseen - permeate outwards to include those who are deceased and those who are yet to come, as well as past and future impacts on the environment. Even thoughts and intentions can come to bear on the natural world and can dictate the reciprocity back from the natural world to the self. (p. 1086, emphasis added)

Knowledge in indigenous onto-epistemologies is derived from sensorial receptivity within the collective realm of the felt and sensed world, an orientation requiring respectful relationality with the more-than-human. Manulani Aluli Meyer (2003), an Indigenous scholar from Hawai'i, describes the multi-sensorial receptiveness that enables traditional Hawaiian learning to occur, 'through psychic connection, experience, dreams, clouds, touching, through revelations and through their intestines' (p.97). Emotions and intellect are seen as being situated in the gut or intestine, compassion and wisdom being felt, coming from the 'place' of emotion.

Over the course of the year, the teachers juxtaposed Māori traditional gardening and harvesting practices with those being carried out within their kindergarten. Traditional practices included: bird-snaring; rat-trapping; preserving game; gathering fish, eels, shellfish and seaweeds; breaking ground and planting of crops; and collecting fungi for medicinal purposes. Kindergarten practices included: planting seeds; weeding raised garden beds; saying a karakia (grace) before meals; composting food scraps; and making vegetable soup. They explained this juxtaposition of traditional and contemporary practices to tamariki (children) and whānau (families) in their pedagogical documentation under the heading: 
Some of the main tasks and work carried out by Maori in pre-European times and some of the tasks and work we carry out now, presented within the framework of ngā marama Māori o te tau' [the Māori moons/months of the year].

In this way, the teachers were revalidating indigenous time-scapes, via a deliberate transgression of linear western modernist assumptions, reconceptualising space-time intra-actions (Haraway, 2008). Each season, they quoted practices described in a traditional maramataka (lunar and seasonal calendar) and then went on to document the parallel contemporary practices at their kindergarten under the heading 'For us it means', as seen in this example from the beginning of the project:

Hōtoke/Takurua - Winter

All things of the earth are contracted owing to the cold, as [are] also the people. For Māori this meant: bird snaring and rat trapping; all game was preserved; Moki, Warehou [types of fish] and kakahi mussels were collected; breaking up new ground for planting of crops began; fungi was collected for medicinal purposes.

For us it means:

23/6/08 At mat-time I talked to the children about gardening and growing plants. I asked 'Shall we grow veggies for the rabbit or veggies to share with all the children and their whanau [families]?'. The children decided that sharing the veggies was what we should do. I told them I would need their help someday soon to get the gardens ready - weeding etc. I also explained that we were going to use the Māori gardening calendar to help us with our gardening work. We made a list of veggies we might like to grow.

25/6/08 M. and her Mum brought in an egg tray, seeds (carrot, broad beans and peas) and a bag of seed raising mix. M. explained really well what we needed to do. Later in the morning several children helped to plants the seeds in the egg trays. Now we have to take care of them and wait!

25/6/08 The children and Judith got outdoors between showers and began weeding the raised garden beds. We talked about getting the gardens ready for planting, and about putting good things back into the soil so our plants will grow well.

The pedagogical documentation over the course of the year of data collection contained a series of photographs and explanations juxtaposing traditional and contemporary seasonal food-gathering practices. During the winter the children were engrossed in weeding gardens, planting seeds, and observing seasonal changes, such as daffodil shoots emerging from the soil. In framing the work of the children alongside the parallel seasonal ecological projects of traditional Māori, the teachers allowed Māori and other children and families to experience a sense of simultaneity of past/present/future providing a counter-narrative to modernist assumptions of linear time progression. This offers a destabilising of 'matters of fact', whilst addressing the 'matter of concern' that indigenous onto-epistemologies have been disregarded.

The teachers went on to describe how the children would say a karakia (a traditional incantation expressing appreciation to the sources of sustenance) before eating morning tea. The children's absorption in working with the soil, seeds, and plants, evident in the photographs and accompanying narratives, suggests that they are operating in a space/place/time which allows for non-cognitive ways of being, knowing and doing. This offers a sense of a pedagogy infused with an ethics of care and affect. Carl Te Hira Mika has explained that from a te ao Māori perspective (Māori worldview), 'Being itself is affected by the interrelationship between the self and the natural world, with the result that speaking, art, silence and contemplation' [and I would add working closely with the earth] are the 'conduit for Being to hold sway'. In this Māori conceptualisation, 'Being is beyond the control of humanity' (2012, p. 1083), although people may seek to invoke this sense of interconnected Being-ness through invocations such as karakia (traditional spiritual incantations). Making time within everyday rituals for karakia, as the Hawera teachers did, is a means of invoking within the children and wider early childhood centre community, a sense of shared purpose and spiritual interconnectedness.

Modernism has created a reliance on pharmaceutical companies as a perceived source of physical and emotional well-being. For Māori, colonisation has produced the 'matter of concern' that traditional knowledges pertaining to health, which were primarily focussed on spiritual well- 
being supported by natural remedies from indigenous plants, have been supplanted by commercial synthetic substances. In te reo Māori (the Māori language) the term 'rongo' means to sense (hear, taste, feel, smell), as well as peace. Rongoā refers to healing remedies, both spiritual and tangible. Implicit is the sense that human well-being depends on sensorial awareness and maintenance of states of interconnected, reciprocal, spiritual well-being within the local ecology. Taking up the notion of rongoā, the teachers began to introduce the story Koro's Medicine (Drewery, 2004) to the children. They observed and documented 'Some ways our environment nurtures our wairua (spirit, spiritual interconnectedness)':

Papatūānuku (Earth Mother) and Ranginui (Sky Father) look after all of us. The sun, wind, rain and air look after the plants that look after us. We are nurturing our tamariki [children] to look after their environment. In caring for our natural environment, the tamariki are developing respectful relationships with nature whilst nurturing their health, well-being and wairua (spirituality/soul) within. The children freely interact with our garden to express their inner thoughts and emotions. Sadly, we lost our pet rabbit, Misty. The children miss our pet rabbit and often pick flowers from our garden or theirs and lay them on the ground by Misty. The children are very observant and notice when the moon is in the daylight sky.

These conceptualisations of well-being include acknowledgement of sentient, emotional connectedness through recognition of whakapapa, genealogical/layered interdependence with the more-than-human and with the wairua (spiritual interconnectedness) that connects and transcends the living and no longer living (Mika, 2012).

In documenting what can be seen as a pedagogy of care and affect, the teachers described the replanting by the children of some potted plants, eliciting the wairua (spiritual interconnectedness) through karakia (incantation), acknowledging sensory awareness of the life force of 'inanimate' objects such as river stones:

Our little pot plants had finished flowering so we recycled them by transplanting succulents in the pots. First we had karakia [blessing, spiritual incantation] to acknowledge Tāne-Mahuta [spiritual guardian of trees, birds, insects and forests], then broke off pieces of the succulent plants, sat them in the pots and watered them. The children carried river stones from the gravel pit and poured them into the planter boxes. We talked about gardening, looking after the plants, where the stones came from and experienced the mauri [life force] in the plants and stones. It was a good team effort. When we had finished, the children admired their work. When one works with Papatūānuku [Earth Mother], one can find it relaxing and peaceful. It teaches patience and nurtures the soul.

The Earth Mother, Papatūānuku, and Sky Father, Ranginui, are the source and sustenance of all entities, interconnected within a wider notion of 'Being', transcendent of a solely humanist focus. The whenua (land) provides life-sustaining abundance for all creatures, as does the whenua (placenta) for the growing foetus. 'Māori do not share the Western concept of animate and inanimate in the natural world. For Māori, all things have a mauri, or life force, and a wairua, or spirit. This is part of why Māori conceive their world in different ways from Westerners. The land, sea, sky, and waters are seen as indivisible' (Waitangi Tribunal, 2004, p. 4). Thus the animate landscape is far more than a merely metaphoric representation of interconnectedness and interbeing-ness between the more-than-human/people as reflected in Māori cosmology and conceptualisation (Marsden, 2003; Mead, 2003; Murton, 2012). Well-being is sourced in a sense of spiritual peace and harmony, rather than via physical measures. Papatūānuku (Earth Mother) is recognised by these educators as a fellow active teacher and source of wisdom. Through entering into deep engagement with caring for Papatūānuku, children enter into a silent dialogic, intersubjective relationship with the more-than-human, an engaged reflexive mutuality (Rose, 2008). The western imposition of division between human and more-than-human, of nature and culture, subsides out of view as the daily work is subsumed within the natureculture of this setting.

As the seasons moved on into Kōanga (Spring), the teachers continued their juxtaposition of traditional and current practices, maintaining, extending, and deepening some of the threads that were woven through their pedagogies. This included a focus on the healing properties of indigenous plants as still practiced by some Māori, particularly elders who encourage respect for the gift of healing offered by these plants: 
The teachers have continued to read Koro's medicine and focused on different aspects of it, then linked it to different things relating to Rongoā.

When Judith read the book on this occasion, the children were making links to the story about how their families treated their cuts, sores and illnesses. Some children showed Judith some of their sores. Koro's medicine was very different to Mum's band aids and medicines from the chemist. The children could see that while there are different remedies, that both worked.

Respect for and validation of Māori ways of being, knowing and doing is here visibilised, alongside recognition of western medical remedies. Whilst the western model of health focuses on decontextualised physical individual treatment, indigenous models of health and well-being focus on harmony 'among persons, and the psychic forces of nature and the supernatural' (Meyer, 2003, p. 109). In the indigenous relatedness onto-epistemology described by Youngblood Henderson, harmonisation is described as a prime ordering principle and goal of indigenous societies:

Our elders say that if we are able to live in harmony we must accept the beauty and limits of our ecology. We must accept our relationships with the surrounding life forces and ourselves as we are. We must be good and kind to all diversity in the circle of life. We must learn to believe and trust the other life forces. (2002, pp. 268-260, as cited in Martin, 2008, p. 86)

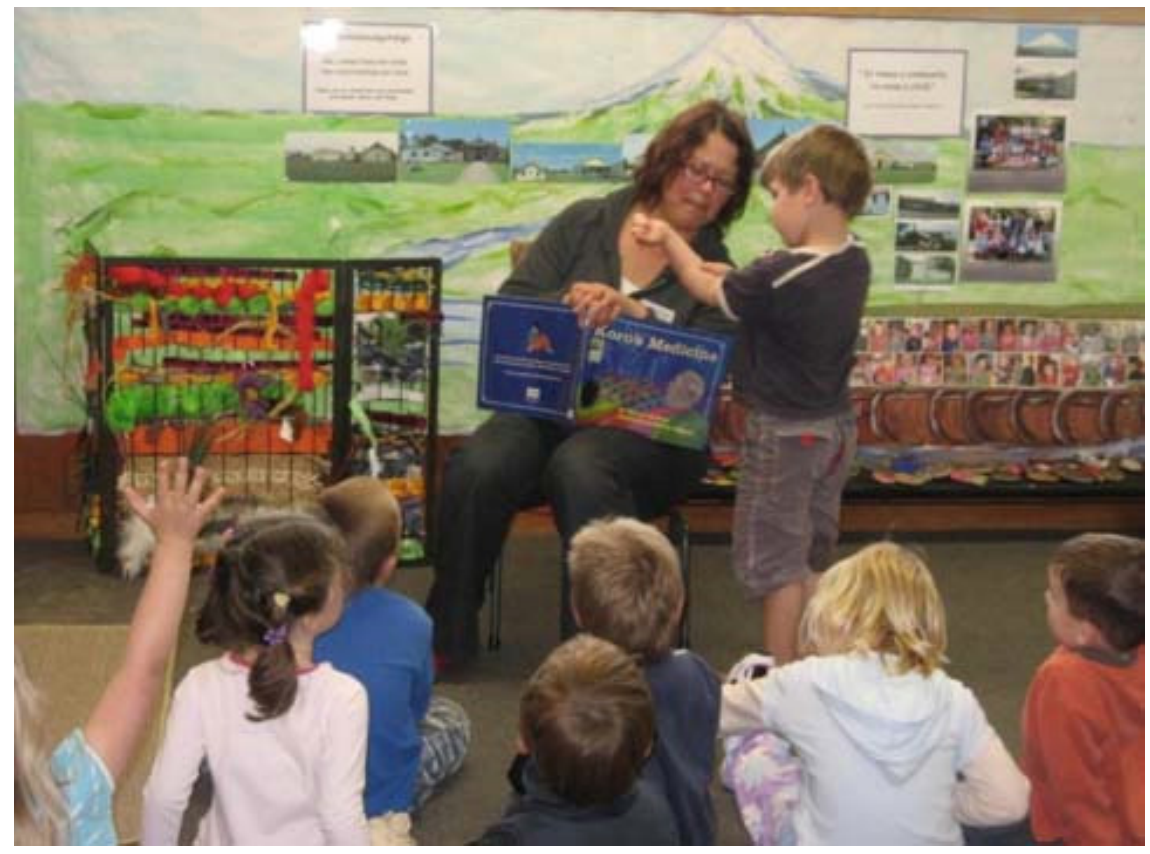

Figure 1. Judith Nowotarski and children of Hawera Kindergarten discussing Koro's Medicine.

In the background of a photo of the mat-time discussion of rongo $\bar{a}$ (see Figure 1) is a wall-display which features the local mountain, Taranaki, in the background, with photographs of various marae (central meeting-house and courtyard of Māori sub-tribes). This visibilises the whakapapa (genealogical connection) of local Māori people, including Māori children and families attending that kindergarten, to their ancestral mountain and river, and mutual interrelationships with the more-than-human are respectfully acknowledged.

In Whiringa $\bar{a} \mathrm{Nuku}$ (October/mid-spring), the documentation of the journey so far in their project was shared with the whänau (families) of the centre via a wall display (see Figure 2). 


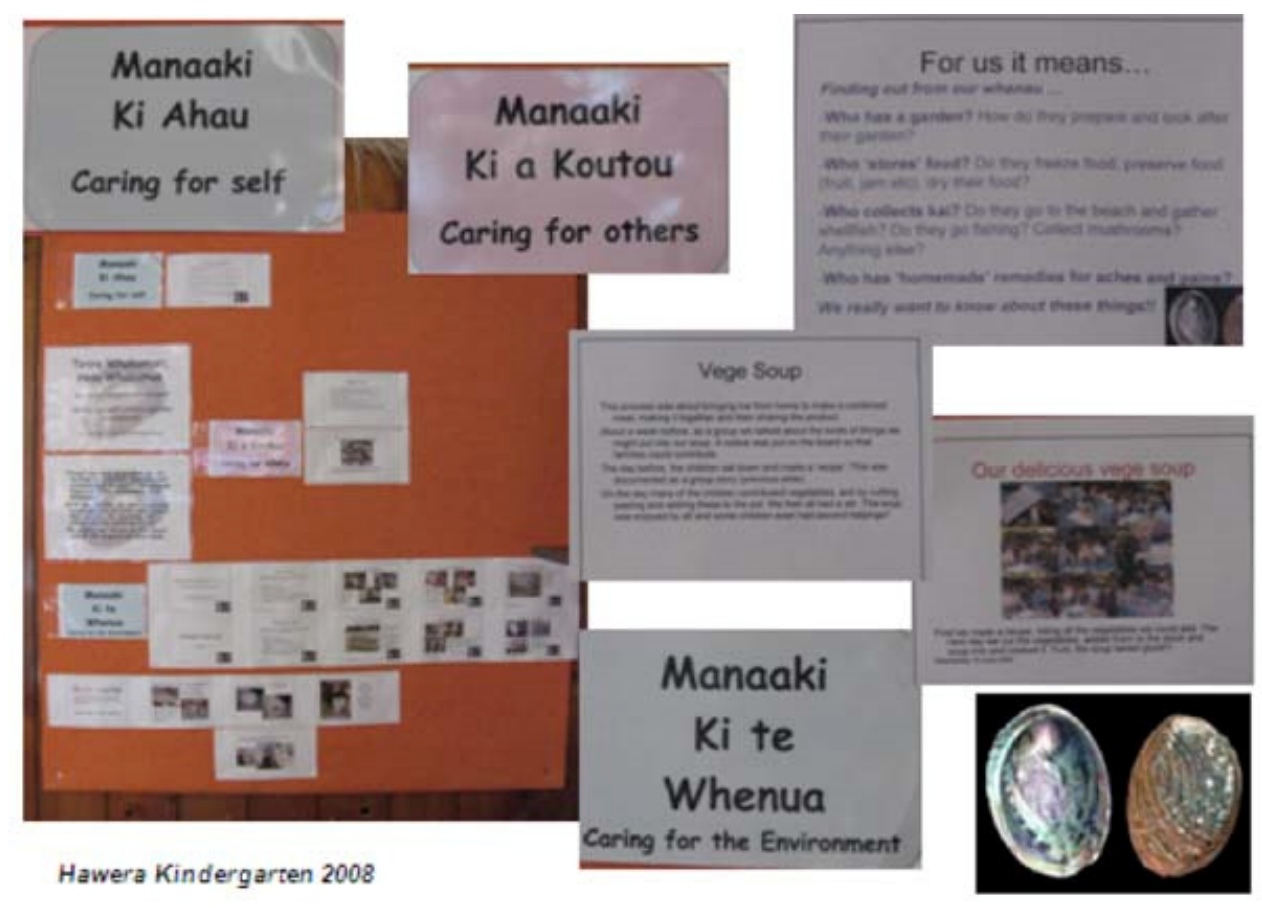

Figure 2. Notice board at Hawera Kindergarten.

In keeping with the Māori perspective symbolised by the koru, an unfurling fern frond representing the spiralling revisiting of understandings (Bishop, 2005), teacher Joy Rangi returned to the kaupapa (focus) of rongoā Māori (Māori healing practices) with the children. She gathered some books with which the children were able to identify some of the healing properties of plants growing in their kindergarten environment. Here is an excerpt from their documentation:

Joy talked about native plants and how Koro used them.

For the children at Hawera Kindergarten, we looked in our playground and found native plants and learnt some of their healing properties.

We used an illustrated book called 'Wai Rakau Essence of the Forest Maori Herbal Remedies' (Maysmor, c2003), about rongoā from native plants. The children took photos and were curious to know what they were for. While Harakeke (flax) was used for Tama's blisters, it was also used to make kete (baskets), whāriki (woven mats) and kākahu (clothing).

Plants we found included Pohutukawa, Ti Kauka, Kōwhai, Kawakawa, Harakeke, Koromiko, Puawānanga and Rahurahu. We also looked at edible plants which included Pūhā, and the vegetables in our gardens, carrots, peas, lettuce, tomato, parsley, coriander.

Joy shared some personal experiences her Mum used, such as applying Pūhā sap to warts.

Joy went on to share with the children narratives of some of the local Māori elders from a book, Matarakau. Ngā kōrero mō ngā rongoā o Taranaki. Healing stories of Taranaki (Tito et al, 2007). This had great resonance with the children, and it transpired that one of the elders whose story was included in this text was the grandmother of one of the children attending the kindergarten at that time. Children were thus reconnecting with indigenous plants and their capacity to serve as rongo $\bar{a}$ (healing properties). This knowledge might otherwise have remained invisible, these plants usually ignored as irrelevant to the educational purposes of the kindergarten, merely decorative shrubs on the periphery. Moreover, this is an example of decolonising renarrativisation, honouring of the intergenerational transmission of traditional wisdoms still upheld by Māori elders within the local community despite over a century of legislative condemnation of traditional healers as dictated by the Tohunga Suppression Act of 1907 (Solomon, 2007; Waitangi Tribunal, 2011). This 
renarrativisation addresses the 'matter of concern' of the suppression of indigenous ways of knowing, being and doing.

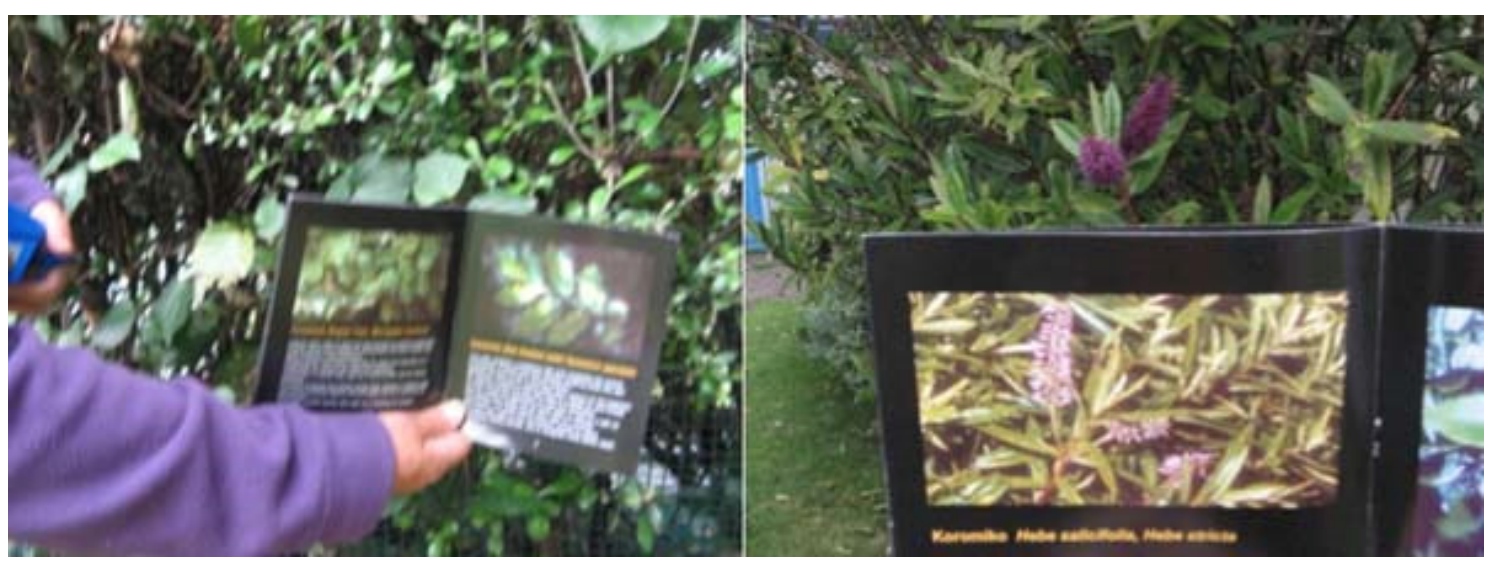

Figure 3. Identifying indigenous plants and their healing properties, Hawera Kindergarten.

\section{Naturecultures Dialogues}

David Abram (1996) reflects upon why and how Western civilisation has become so estranged from the more-than-human world to the point that 'our current lifestyles contribute daily to the destruction of whole eco-systems - whole forests, river valleys, oceans - and to the extinction of countless species'. He asks: 'How did civilized humankind lose all sense of reciprocity and relationship with the animate natural world, that rapport that so influences (and limits) the activities of most indigenous, tribal peoples?' (p. 137). How is it that our dominant Western discourses no longer 'make sense' - in the literal meaning of enlivening our senses (p. 265) - are so discordant, so disharmonious, so dislocated from the stories of the land that would sustain all those who live upon it (Chamberlin, 2004)?

Donna Haraway (2008) suggests the need for rethinking western, modernist patterns of relationality and 'intra-actions at many scales of space-time' (p. 17). Whilst the western project has objectified 'nature' as a resource, Indigenous onto-epistemologies operate within a natureculture dialogue, in which 'Every act, element, plant, animal and natural process is considered to have a moving spirit with which humans continually communicate' (Cajete, 2000, p. 69, as cited in Four Arrows \& Miller, 2012, p. 48). Indigenous onto-epistomologies have emerged from a deep interconnectedness and interrelatedness within specific ecologies of place/space/time. These naturecultures dialogues, despite having been submerged and displaced by colonisation, still have the potential to influence both post/counter-colonial (Johnson \& Murton, 2007) and post/counterAnthropocence possibilities (Kuecker \& Hall, 2011).

Indigenous ways of knowing, being and doing reflect modes of communities living respectfully and responsively within specific locales (Kuecker \& Hall, 2011). The Māori cosmology positions people alongside plants, birds and insects as fellow offspring of Papatūānuku, Earth Mother and Ranginui, Sky Father. Constructs such as mana whenua (genealogical connection to specific lands), kaitiakitanga (guardianship over rivers, lakes and lands), tino rangatiratanga (use of authority to ensure the well-being of resources and people), mauri (life force of animate and inanimate things), and wairuatanga (spiritual interconnectedness) reflect the respectful role of humans within their realm of influence.

\section{Pedagogies of Care and Affect as Postcolonial Naturecultures Praxis}

In this article I have described some pedagogical responses to two interrelated 'matters of concern': the invisibilisation of indigenous onto-epistemologies by the colonialist project, and anthropogenic climate change. These two concerns share the same source, the global technicist, corporatist exploitation of human and natural resources. It is the argument of this article that traditional, Indigenous peoples hold the onto-epistemological tools which enable sustained living in 
relationship with the more-than-human, through localised natureculture dialogues. It is suggested that educators have the response-ability to generate pedagogies of care and affect that operate in ways that are restorative of an ethic of biocentric relationality (Ritchie, 2013). These pedagogies of care and affect, which can be informed by indigenous worldviews that uphold caring for the Earth (Mother) and Sky (Father), are an everyday praxis in response to anthropogenic climate change.

The article has outlined some ways that the teachers of Hawera Kindergarten revisibilised life-sustaining Māori traditional seasonal and healing practices, integrating these within their daily pedagogies. It has been suggested that these pedagogies resonating care and affect offer some movement towards transcending the ongoing disruption and intergenerational pain of colonisation. The enactment of tikanga Māori (Māori ethics of correct behaviour and practices), furthermore, demonstrated dispositions of reciprocal respectful relationships with the more-thanhuman. These tikanga were incorporated into daily rituals, such as saying karakia (spiritual incantation) before meals or prior to gardening, expressing respect and reciprocal engagement with the more-than-human. Well-being was recognised by these teachers as not merely a physical condition, but as something that is dependent on spiritual interconnectedness with the land, earth, animals, plants, air and sunshine, as seen in the way the teachers documented 'Some ways our environment nurtures our wairua [spirit, spiritual interconnectedness]'. The pedagogical focus on well-being continued through the pursuit of interest in rongōa Māori (Māori healing practices), which includes recognition of kai Māori (traditional local Māori foods) as a source of healing and well-being. Working in their gardens on a daily basis, the children and teachers experienced the healing power of 'working with Papatūānuku' (Earth Mother) as restorative of the wairua, generating a feeling of peace, well-being and relaxation, and as a source of wisdom. Perhaps practices such as these can be seen as an Indigenous-informed Earth-wise historiography (Rose, 2008), an alternative naturecultures praxis that fosters relational and collective dispositions (Taylor, 2013) of ethical, compassionate, responsive care for both self and 'Others', the Earth, the morethan-human. It is also possible that such pedagogies may foster multi-sensorially felt and known awareness of naturecultures, an ecological consciousness (Oliver, 2009) founded in sensory-derived recognition of our interdependence with, and dependence upon, the more-than-human in our entangled common worlds (Taylor \& Giugni, 2012; Taylor, 2013). At this point in the Anthropocene, this pedagogical intention is undoubtedly a critical matter of concern, affect, and care.

\section{Notes}

[1] Haraway's term 'response-ability' can be read as a call to action. Haraway has written that 'We are all responsible to and for shaping conditions for multispecies flourishing in the face of terrible histories, but not in the same ways. The differences matter - in ecologies, economies, species, lives' (2012, p. 314). Haraway's term 'response-ability' stresses that we are all able, although in different ways, to respond to the climate crisis.

[2] Following Haraway, I use the hyphenated term 'adapt-ability' to emphasise the capacity for agency in response to the climate crisis.

[3] It should be noted that all translations into English need to be treated as objectifying, representational interpretations, which have colonised Māori ways of knowing, being and doing (Mika, 2012).

\section{References}

Abram, D. (1996) The Spell of the Sensuous. Perception and Language in a More-than-Human World. New York: Vintage Books.

Alberts, P. (2011) Responsibility towards Life in the Early Anthropocene, Angelaki, 16(4), 5-17.

Bell, A. (2009) A Conversation through History: towards postcolonial coexistence, Journal of Intercultural Studies, 30(2), 173-191. http: / / dx.doi.org/10.1080/07256860902766974

Bishop, R. (2005) Freeing Ourselves from Neocolonial Domination in Research: a Kaupapa Māori approach to creating knowledge, in N. K. Denzin \& Y.S. Lincoln (Eds) The Sage Handbook of Qualitative Research, 3rd edn, pp. 109-164). Thousand Oaks, CA: Sage. 
Indigenous Onto-Epistemologies and Pedagogies of Care and Affect

Bowers, C. (2001) How Language Limits Our Understanding of Environmental Education, Environmental Education Research, 7(2), 141-151. http: / / dx.doi.org/10.1080/ 13504620120043144

Cajete, G.A. (2005) American Indian epistemologies, New Directions for Student Services, 109, 69-78. http: / / dx.doi.org/10.1002/ss.155

Chamberlin, J.E. (2004) If This is Your Land, Where are Your Stories? Finding Common Ground. Toronto: Vintage Canada.

Costello, A., Abbas, M., Allen, A., Ball, S., Bell, S., Bellamy, R., et al (2009) Managing the Health Effects of Climate Change, The Lancet, 373(9676), 1693-1733. http:/ / dx.doi.org/10.1016/S0140-6736(09)60935-1

Drewery, M. (2004) Koro's Medicine. Wellington: Huia.

Four Arrows, \& Miller, J. (2012) Holistic and Indigenous Education: a dialogue, ENCOUNTER, 25(3), 44-54.

Gorenflo, L.J., Romaine, S., Mittermeier, R.A. \& Walker-Painemilla, K. (2012) Co-occurrence of Linguistic and Biological Diversity in Biodiversity Hotspots and High Biodiversity Wilderness Areas, Proceedings of the National Academy of Sciences of the United States of America, 109(21), 8032-8037. http: / / www.pnas.org/ content/8109/8021/8032

Haraway, D.J. (2008) When Species Meet. Minneapolis, MN: University of Minnesota Press.

Haraway, D.J. (2012) Awash in Urine: DES and Premarin $₫$ in multispecies response-ability, Women's Studies Quarterly, 40(1-2), 301-316.

Intergovernmental Panel on Climate Change (2013) Working Group I Contribution to the IPCC Fifth Assessment Report Climate Change 2013: the physical science basis. Summary for Policymakers. http: / / www.ipcc.ch/index.htm\#.Uk4dnVP4WSo.

Johnson, J.T. \& Murton, B. (2007) Re/placing Native Science: indigenous voices in contemporary constructions of nature, Geographical Research, 45(2), 121-129. http:/ / dx.doi.org/10.1111/j.17455871.2007.00442.x

Kuecker, G.D. \& Hall, T.D. (2011) Resilience and Community in the Age of World-System Collapse, Nature \& Culture, 6(1), 18-40. http:/ / dx.doi.org/10.3167/nc.2011.060102

Latour, B. (2004a) Politics of Nature. How to Bring the Sciences in to Democracy. Cambridge, MA: Harvard University Press.

Latour, B. (2004b) Why has Critique Run Out of Steam? From Matters of Fact to Matters of Concern, Critical Inquiry, 30(2), 225-248. http:// dx.doi.org/10.1086/421123

Levinas, E. (1987) Time and the Other, trans. R.A. Cohen. Pitttsburgh, PA: Duquesne University Press.

Lorimer, J. (2012) Multinatural Geographies for the Anthropocene, Progress in Human Geography, 36(5), 593-612. http: / / dx.doi.org/10.1177/0309132511435352

Marsden, M. (2003) The Woven Universe. Selected Writings of Rev. Māori Marsden, ed. T.A.C. Royal. Wellington: The Estate of Māori Marsden.

Martin, K. (2007) Making Tracks and Reconceptualising Aboriginal Early Childhood Education: an Aboriginal Australian perspective, Childrenz Issues, 11(1), 15-20.

Martin, K. (2008) Please Knock Before You Enter. Aboriginal Regulation of Outsiders and the Implications for Researchers. Teneriffe, QLD: Post Pressed.

Mead, H.M. (2003) Tikanga Māori. Living by Māori Values. Wellington: Huia.

Meyer, M.A. (2003) Ho'oulu: our time of becoming Hawaiian epistemology and early writings. Honolulu, HI: Ai Pohaku Press.

Mika, C.T. (2012) Overcoming 'Being' in Favour of Knowledge: the fixing effect of 'mātauranga', Educational Philosophy and Theory, 44(10), 1080-1092. http:/ / dx.doi.org/10.1111/j.1469-5812.2011.00771.x

Murton, B. (2012) Being in the Place World: toward a Māori 'geographical self, Journal of Cultural Geography, 29(1), 87-104. http:/ / dx.doi.org/10.1080/08873631.2012.655032

Oliver, K. (2009) Animal Lessons. How They Teach Us to be Human. New York: Columbia University Press.

Penetito, W. (2009) Place-Based Education: catering for curriculum, culture and community, New Zealand Annual Review of Education, 18, 5-29.

Puig de la Bellacasa, M. (2012) 'Nothing comes without its world': thinking with care, The Sociological Review, 60(2), 197-216. http:/ / dx.doi.org/10.1111/j.1467-954X.2012.02070.x

Ritchie, J. (2013) A Pedagogy of Biocentric Relationality, New Zealand Journal of Educational Studies, 48(1), 34-49.

Ritchie, J., Duhn, I., Rau, C. \& Craw, J. (2010) Titiro Whakamuri, Hoki Whakamua. We are the Future, the Present and the Past: caring for self, others and the environment in early years' teaching and learning. Final Report 
for the Teaching and Learning Research Initiative. Wellington: Teaching and Learning Research Initiative and New Zealand Centre for Educational Research. http:/ / www.tlri.org.nz/tlri-research/researchcompleted/ece-sector/titiro-whakamuri-hoki-whakamua-we-are-future-present-and

Rose, D.B. (2002) Dialogue with Place: Toward an ecological body, Journal of Narrative Theory, 32(3), 311-325. http:/ / dx.doi.org/10.1353/jnt.2011.0054

Rose, D.B. (2004) Reports from a Wild Country. Ethics for Decolonisation. Sydney: University of New South Wales.

Rose, D. (2005) An Indigenous Philosophical Ecology: situating the human, Australian Journal of Anthropology, 16(3), 294-305. http:/ / dx.doi.org/10.1111/j.1835-9310.2005.tb00312.x

Rose, D.B. (2008) On History, Trees, and Ethical Proximity, Postcolonial Studies, 11(2), 157-167. http: / / dx.doi.org/10.1080/13688790802004687

Rose, D.B. (2009) Love in the Time of Extinctions, Australian Journal of Anthropology, 19(1), 81-84. http: / / dx.doi.org/10.1111/j.1835-9310.2008.tb00112.x

Rose, D.B., Cooke, S. \& van Dooren, T. (2011) Ravens at Play, Cultural Studies Review, 17(2), 326-343.

Smith, L.T. (1999/2012) Decolonizing Methodologies. Research and Indigenous Peoples. London: Zed Books and University of Otago Press.

Solomon, M. (2007) A Long Wait for Justice, in M. Bargh (Ed.) Resistance. A Maori Response to Neolliberalism, pp. 75-84. Wellington: Huia.

Taylor, A. (2013) Reconfiguring the Natures of Childhood. Abingdon: Routledge.

Taylor, A. \& Giugni, M. (2012) Common Worlds: reconceptualising inclusion in early childhood communities, Contemporary Issues in Early Childhood, 13(2), 108-119. http: / / dx.doi.org/10.2304/ ciec.2012.13.2.108

Tito, J., Pihama, L., Reinfeld, M. \& Singer, N. (Eds) (2007) Matarakau. Ngā kōrero mō ngā rongoā o Taranaki: healing stories of Taranaki. Taranaki: Karangaora.

Waitangi Tribunal (2004) Report on the Crown's Foreshore and Seabed Policy. Wai 1071. Wellington: Legislation Direct. http: / www.waitangi-

tribunal.govt.nz/reports/viewchapter.asp?reportID=838C5579-36C3-4CE2-A444-

E6CFB1D4FA01\&chapter=3.

Waitangi Tribunal (2011) Ko Aotearoa Tènei. A Report into Claims Concerning New Zealand Law and Policy Affecting Māori Culture and Identity. Te Taumata Tuarua. Vol. 2. Wellington: Waitangi Tribunal. http: / / www.waitangitribunal.govt.nz/reports/downloadpdf.asp?ReportID $=\{$ BF981901-5B55-441CA93E-8E84B67B76E9\}

Whitehouse, H. (2011) Talking Up Country: language, natureculture and interculture in Australian environmental education research, Australian Journal of Environmental Education, 27(1), 56-67. http: / / dx.doi.org/10.1017/S0814062600000070

JENNY RITCHIE currently holds the position of Associate Professor in Early Childhood Teacher Education at Te Whare Wānanga o Wairaka - Unitec Institute of Technology, Auckland, New Zealand. Her teaching and research focus on cultural, environmental and social justice issues. Correspondence: jritchie@unitec.ac.nz 